
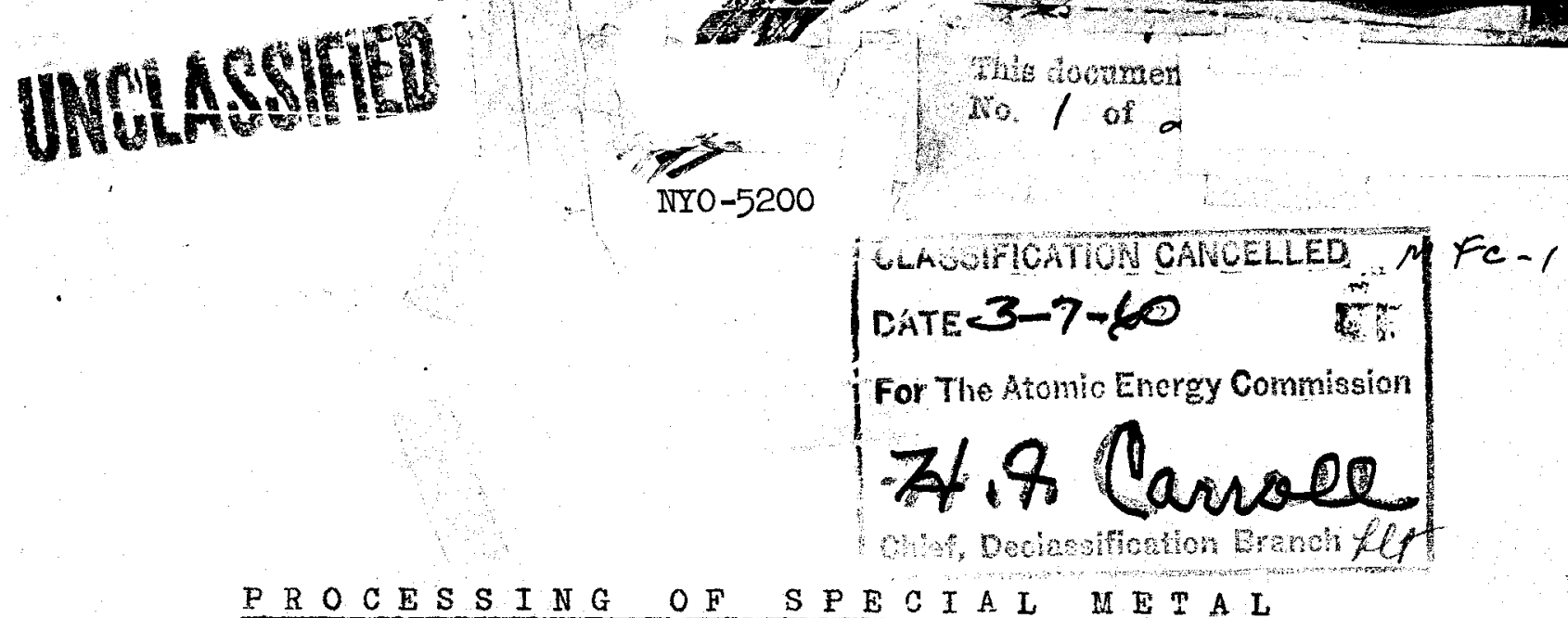

PROCESSING OF SPECIAL MEIAL \%

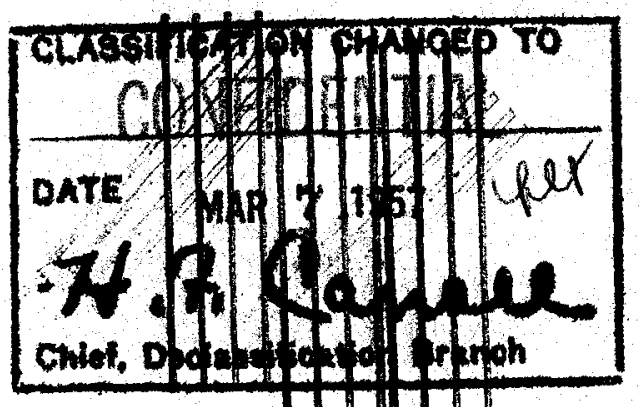

FOR H A N F OR D

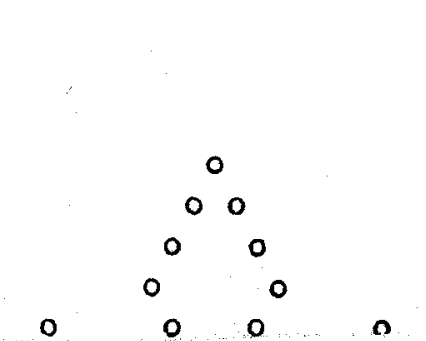

\section{LEGAL NOTICE}

This report was prepared as an account of Government sponsoned work. Neither the United States, nor the Commission, nor any person acting on behalf of the Commission:

A. Makes any warranty or representation, express or implied, with respect to the accuracy, completeness, or usefulness of the information contained in this report, or that the use of any information, apparatus, method, or process disclosed in this report may not infringe privately owned rights; or

B. Assumes any liabilities with respect to the use of, or for damages resulting from the we of any information, apparatus, method, or process disclosed in this report.

As used in the above, "person acting on behalf of the Commission" includes any empbyee or contractor of the Commission to the extent that such employee or contractor pepares, handles or distributes, or provides access to, any information pursuant to his emplyment or contract with the Commission.

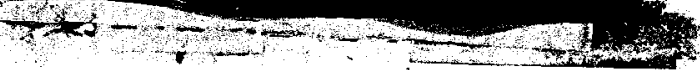

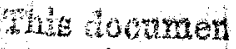

No. 1 of a

\title{
ATE 3-7-60
}

or The Atomic Energy Commission

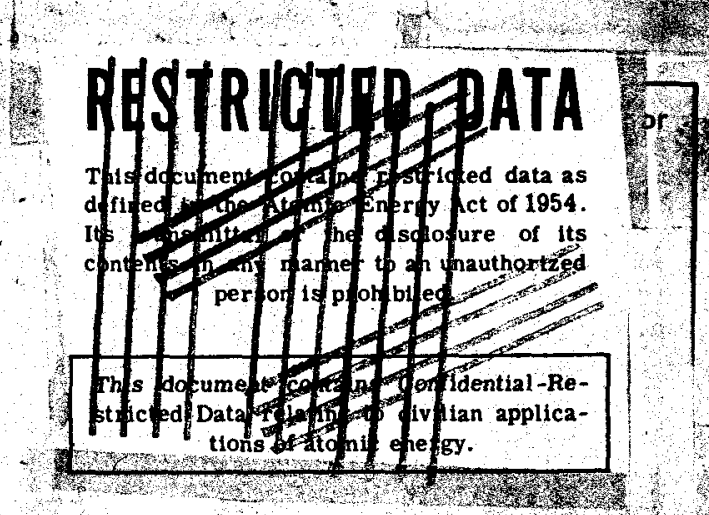
PUBLICLY RELEASABLE JRO Review Team Authorizing Official Date $11-9-2010$

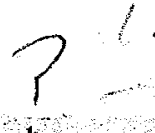
d 


\section{DISCLAIMER}

This report was prepared as an account of work sponsored by an agency of the United States Government. Neither the United States Government nor any agency Thereof, nor any of their employees, makes any warranty, express or implied, or assumes any legal liability or responsibility for the accuracy, completeness, or usefulness of any information, apparatus, product, or process disclosed, or represents that its use would not infringe privately owned rights. Reference herein to any specific commercial product, process, or service by trade name, trademark, manufacturer, or otherwise does not necessarily constitute or imply its endorsement, recommendation, or favoring by the United States Government or any agency thereof. The views and opinions of authors expressed herein do not necessarily state or reflect those of the United States Government or any agency thereof. 


\section{DISCLAIMER}

Portions of this document may be illegible in electronic image products. Images are produced from the best available original document. 


\section{PROCESSING OF SPECIAL: METAL}

\section{FOR HANFORD}

\section{Object}

To reduce the impurities and raise the density of rejected slugs and briquetted turnings from these slugs by recasting the material.

Discussion

Experience has shown that metal high in nitrogen could be greatly decreased in nitrogen content by recasting. As high nitrogen metal is low in density because of the nitrogen content, the recast metal being very low nitrogen is also improved in density. Impurities such as iron cannot be redused by recasting, but they a re not increased in that operation, so the overall quality is greatly improved. Some impuritios like oarbon and silica are probably increased slightly by recasting.

With the above facts in mind, the Hanford Engineer Works requested that $M, C . W$. recast some low quality slugs and some briquetted turnings made from the scrap left when these slugs were machined. A program was outlined by the Hanford poople, and Mr. E. A. Smith and Mr. T. Jones of Hanford visited our plant to watch the processing of the material. The original program was changed somewhat after several runs had been made and not all the metal was recast for reasons which will be stated later.

We started out by recasting the slugs. The metal acted very peculiarly in that it did not boil at all in the crucible and loft a very heary film on top of the melt. When the material was poured, it appeared to be very viscous and gave very poor yields when only heated to the pouring temperature of virgin metal biscuits. After the pour sempleted, metal kept running out of the crucible which pointed to the fact that there was a large "heel" in the crucible which was honeycombed with molten metal slowly working its way down to the pouring hole. It was quite evident that the metal would have to be heated much hotter than virgin metal to make it fluid enough for a good yield.

The history of the runs made is tabulated in Table I. Column one gives the run number, column two the type of material, and column three the total weight of the charge. Columns four and five give the heating procedure and the heating time required to get the metal ready to pour. Column six gives the yield of recast metal obtained from the charge and column seven lists the observations from each run. 
The following conclusions have been drawn from a study of Table I:

1. Slugs run by themselves should be heated to $2500^{\circ} \mathrm{F}$, cooled to $2400^{\circ} \mathrm{F}$ and poured. This procedure makes the metal fluid enough to give good yields and by cooling down before pouring it gives the impurities time to float out. Slugs run at a lower temperature than this give metal which is too viscous to flow freely with resulting low yields.

2. Mixing virgin metal with slugs does not materially increase the yield but helps the impurities like iron by virtue of dilution. The density of the material and the nitrogen content are no better than when slugs are run alone. The mixture of biscuits and slugs need not be heated to $2500^{\circ} \mathrm{F}$ because there is enough virgin metal present to make the other material fluid. There is also some boiling off of impurities in the virgin metal, causing agitation in the melt which is beneficial. Virgin metal cast with good slugs gives a slightly better yield than running virgin metal alone.

3. Briquettes run by themselves give poor yields, probably because of their high oxide oontent. This oxide greatly decreases the fluidity of the material and gives a poor yield. The briquettes also contained a la rge amount of added magnesium which does not help the yield or the quality. We are not aware of the reasons for dding this magnesium. This material boiled out of the melt and colleoted on the water cooled lid, and a good share of it got into the vacuum system. This is dangerous because the magnesium burns spontaneously when exposed to air and in some instances ignites so rapidly it causes an explosion. This occurs both on the lids and in the vacuum lines, where it is doubly dangerous, as an explosion in the racuum pipes blows the meterial out any oponing with quite a bit of force. It is our opinion that the magnesium should not be added to the briquettes at all.

4. Slugs and briquettes give a slightly lower yield than is obtained by mixing briquettes with virgin metel. The physical plaoing of the material in the crucible has no effect on yield or purity of the metal. This has been further substantiated in our own plant with sawdust and croppings or virgin metal. A long prorram would prove which was the best method of recasting the briquettes, that is, whether they should be cast alone or with slugs to get the best overall yield. 
5. Briquettes and/or slugs will be very hard on graphite crucibles. Out of thirteen runs, nine crucibles were broken. In the processing of virgin material, seven to eight heats per crucible can be expected. The large heel formed by the residual meterial from the low yields broke fire of the crucibles in the furnace and the other four broke on the fire while burning out. This is the process where the residual material in the crucible is burned out by a gas flame. Again, a long program might point the way to better graphite usage.

6. The program was stopped when all the slugs were recast and enough of the briquettes had been used to give an indication of what could be done with them. The rest of the briquettes were not recast because of the difficulties stated above, namely:

1) The briquettes contained too much magnesium.

2) The yields were so low from the briquettes that the residual material in the orucible caused the crucible to break.

Three billets were made in all the heats where there was enough metal to do so. In each case, these billets were stamped with the hoat number and the billet position in the pour. A bill at stamped " $3 B^{\text {", }}$ for instance, would mean that this billet was from the third heat made and was the second billet poured in that heat. An additional egg was poured in all heats rogardless of the number of billets poured and was designated the heat number and the letter "D". These eggs, being low in density, were very difficult to cut to $1900 \pm 60$ grams and consequently, a number of the eggs are outside these tolerances. These eggs wore also very hard and consequently were tough to saw. As high as three sewblades were used in making a cut through an $g g$. This situation made it impossible to cut samplos from these last eggs, as the blades run out on thin cuts of very hard material. (That is, the blade cuts through the side of the slice instead of going straight through the out.)

Some of the billets are shorter than 10 inches, but it was decided that some benefit could be derived by sending these billets on rather than putting them in scrap. 


\section{Analytical Data}

The Hanford people requested that, in addition to regular analyses, our laboratory shculd run chromium, copper, lead, tin, aluminum and oxygen, if the program did not seriously interfere with the normal functions of the laboratory. The laboratory was not set up to run oxygen or chromium and therefore did not do so because of the time involved in setting up the tests.

Three sample slices were cut from each egg and a set of these slices will be sent to fanford to get checks on the analyses run by our laboratory.

The analytical results are listed in Table II. All the analyses are shown with the exception of carbon and hydrogen, which will be reported at a later date. The data sent to us by Hanford listed the density of the metal to be recast as 18.1 to 18.62 with an average density of 18.47 (weighted calculation). The first column of Table II shows the enalytical results from a slug or rod picked at random and tested. As can be seen, the nitrogen is very high in this material, but all the rest of the impurities seem to be quite low. This slug was probably not tco representative of all the metal, as later analyses show some impurities to be higher and these elements are not usually increased by recasting.

It is evident that the samples from heat number one got switched, as the results show billet $I \mathrm{~A}$ to be lower density and higher in impurities than billet $1 \mathrm{C}$, whj oh experience has shown is impossible.

As oan be seen from the table, the metal was considerably improved in density and nitrogen content by recasting, and the other jmpurities are low enough to not cause any trouble. Iron in the metal cannot be removed by recasting, but, as can be seen from heats five, eleven and twelve, it can be improved by dilution with virgin metal, as this material runs between 30 and $40 \mathrm{ppm}$ iron. In some instances, the quality of the third billet in the heat was low, but this could be expected, as the bad metal floats to the top of the melt and would be poured out in the last billet.

Summary and Conclusions

1. Slugs and briquettes made from turnings produced when these slugs were machined can bo recast with great improvement in quality.

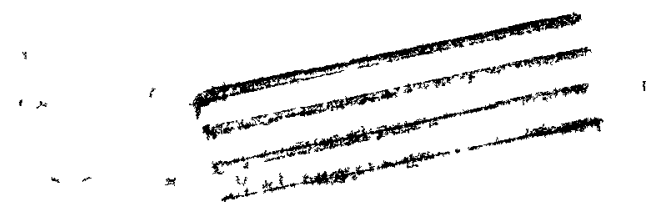


2. Casting this material is quite hard on graphite crucibles, but a longmrange program might point the way to better graphite usage.

3. This metal run alone gives fair yields $(88.8 \%$ to $94.8 \%)$ if heated to $2500^{\circ} \mathrm{F}$ and then cooled to $2400^{\circ}$ before pouring. Mixing with virgin metal improves the final quality, but does not materially increase the yield.

4. Briquettes should not be mixed with magnessium before recasting.

WAOpnold

$\operatorname{map}$ 


\begin{tabular}{|c|c|c|c|c|c|c|}
\hline \multirow[b]{2}{*}{$\begin{array}{c}\text { Run } \\
\text { Number } \\
\end{array}$} & \multirow[b]{2}{*}{ Type Material } & \multirow[b]{2}{*}{ Charge } & \multirow[b]{2}{*}{$\begin{array}{l}\text { Heating } \\
\text { Procedure }\end{array}$} & 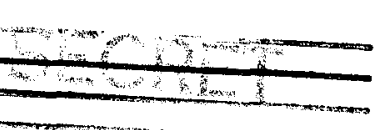 & \multirow[b]{2}{*}{ Yjeld } & \multirow[b]{2}{*}{ Remarks } \\
\hline & & & & $\begin{array}{c}\text { Heating } \\
\text { Time }\end{array}$ & & \\
\hline $1^{*}$ & $\begin{array}{l}\text { Can } 1 \text { and } 2 . \text { Com- } \\
\text { plete } 128.3 \text { lbs. } \\
\text { Can 3. Slugs. }\end{array}$ & 422.38 & $\begin{array}{l}\text { Heat to } \\
2400^{\circ} \mathrm{F} \\
\text { Cool to } \\
2350 \text { and } \\
\text { Pour. }\end{array}$ & $2 \mathrm{hr} .1 \mathrm{~min}$ & $81.6 \%$ & $\begin{array}{l}\text { No. I mold boiled, No. } 2 \text { mold } \\
\text { filled evenly, } 3 \text { rd mold } 1 / 2 \text { full } \\
\text {-metal very viscous. Metel } \\
\text { kept running out after pour was } \\
\text { completed. Xble broke in fur } \\
\text { nace. 4th egg extra hard. }\end{array}$ \\
\hline $2^{*}$ & $\begin{array}{l}\text { Cans } 4 \text { and } 5 \text {. } \\
\text { Slugs. }\end{array}$ & $\begin{array}{l}420.73 \\
\text { el in } x \\
\text { trong } \mathrm{NH}\end{array}$ & $\begin{array}{l}\text { Heat to } 24.00 . \\
\text { Pour. } \\
\text { le quenched in } \\
\text { smell given of }\end{array}$ & $\begin{array}{l}2 \mathrm{hr} .1 \mathrm{~min} . \\
\mathrm{H}_{2} \mathrm{O} \text {-red hot. } \\
\mathrm{f} .\end{array}$ & 86.8 & $\begin{array}{l}\text { No. I mold boiled hard, No. } 2 \\
\text { mold boiled hard, No. } 3 \text { mold } 1 / 2 \\
\text { full. Very viscous metal. Ran } \\
\text { out after pour. Xble broke in } \\
\text { furnace. }\end{array}$ \\
\hline $3^{*}$ & $\begin{array}{l}\text { Cans } 6 \text { and } 7 \text { and } \\
7.52 \text { ibs. Can } 3 . \\
\text { Slugs. }\end{array}$ & 420.36 & $\begin{array}{l}\text { Heat to } 2400 \text {, } \\
\text { cool to } 2350 \text {, } \\
\text { hold } 5 \mathrm{~min} . \\
\text { and pour. }\end{array}$ & $2 h r .5$ min. & 86.5 & $\begin{array}{l}\text { No. I mold boiled hard. No. } 2 \\
\text { mold filled } 9 \text { tenly. No. } 3 \text { mold } \\
1 / 2 \text { full. Evidence of sublimate } \\
\text { on molds in bottom of furnace. } \\
\mathrm{Xble} \text { broke on fire. }\end{array}$ \\
\hline $4^{*}$ & $\begin{array}{l}\text { Cans } 8 \text { and } 9 \text {, } \\
15.21 \mathrm{bs} \text {. Can } 3 \\
\text { and } 15.5 \text { 1bs. } \\
\text { Can 18. Slugs. }\end{array}$ & 423.24 & $\begin{array}{l}\text { Heat to } 2500 \\
\text { cool to } 2400 \\
\text { pour. }\end{array}$ & $2 \mathrm{hr} .6 \mathrm{~min}$ & 88.8 & $\begin{array}{l}\text { All molds boiled, no evidence of } \\
\text { sublimate. Two full molds and } \\
3 \text { rd mold } 2 / 3 \text { full. Xble broke } \\
\text { in furnace. Metal very fluid. }\end{array}$ \\
\hline
\end{tabular}

* No boiling in cruoible.

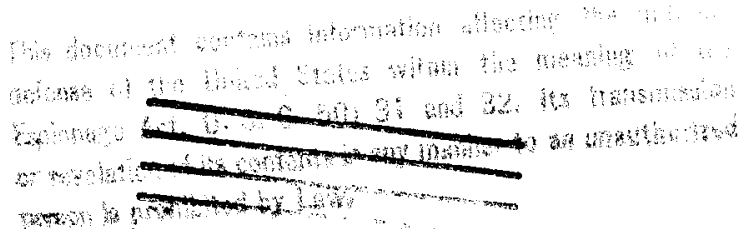




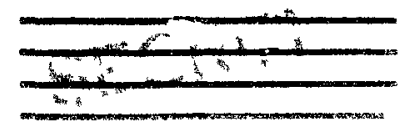

TABLE I (cont'd)

\begin{tabular}{|c|c|c|c|c|c|c|}
\hline $\begin{array}{c}\text { Run } \\
\text { Number }\end{array}$ & Type Material & Charge & $\begin{array}{c}\text { Heating } \\
\text { Prooedure } \\
\end{array}$ & $\begin{array}{l}\text { Heating } \\
\text { Time }\end{array}$ & Yield & Remarks \\
\hline 5 & $\begin{array}{l}2 \text { virgin biscuits, } \\
\text { Can } 10 \text { and } 54.3 \text { Ibs. } \\
\text { Can 11. Slugs. }\end{array}$ & 454.35 & $\begin{array}{l}\text { Heat to } 2400 \text {, } \\
\text { cool to } 2350 \text {, } \\
\text { pour. }\end{array}$ & $1 \mathrm{hr} .49 \mathrm{~min}$. & 95.7 & $\begin{array}{l}\text { Three full molds, all molds } \\
\text { boiled, good caps, metol very } \\
\text { fluid. Metal boiled in xble. } \\
\text { Xble did not break. }\end{array}$ \\
\hline
\end{tabular}

\begin{tabular}{|c|c|c|c|c|c|}
\hline 6 & $\begin{array}{l}\text { Can } 28 \text { and } 84.7 \text { lbs. } 300.7 \\
\text { Can 30. Briquettes. }\end{array}$ & $\begin{array}{l}\text { Heat to } 2400, \\
\text { pour. } \\
\text { Boiled during }\end{array}$ & $\begin{array}{l}1 \mathrm{hr} .32 \mathrm{~min} . \\
\text { melting. }\end{array}$ & & $\begin{array}{l}\text { No. I boiled, 2nd mold } 1 / 2 \text { full } \\
\text { Metal very vis cous, xble broke } \\
\text { in furnace. Large deposits of } \\
\text { Mg on lid of furnaoe. }\end{array}$ \\
\hline
\end{tabular}

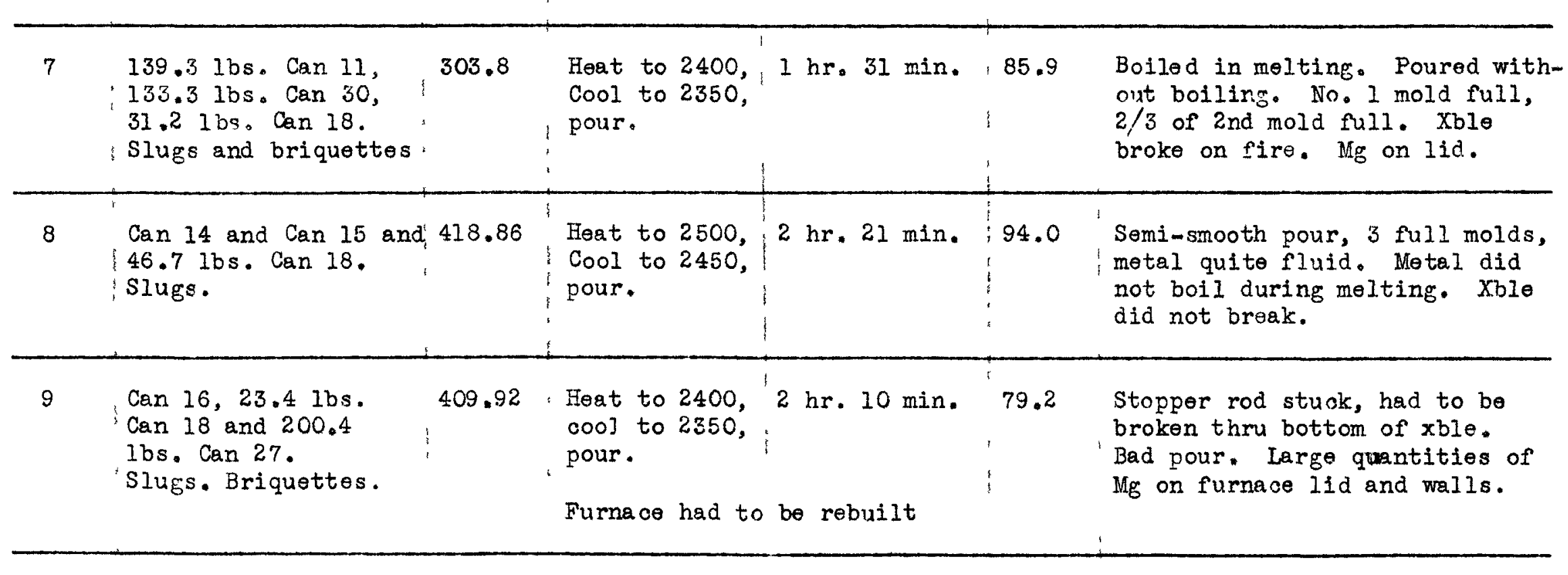


TABLE I (oont'd)

\begin{tabular}{|c|c|c|c|c|c|c|}
\hline $\begin{array}{c}\text { Run } \\
\text { Number }\end{array}$ & Type Material & Charge & $\begin{array}{c}\text { Heating } \\
\text { Prooedure } \\
\end{array}$ & $\begin{array}{l}\text { Heating } \\
\text { Time }\end{array}$ & Yield & Remarks \\
\hline 10 & $\begin{array}{l}\text { Can } 17,190.7 \mathrm{lbs} . \\
\text { Can } 29,23.4 \mathrm{bs} . \\
\text { Can } 18 . \text { Slugs. } \\
\text { Briquettes. } \\
10 \text { grams } \mathrm{MgF}_{2}\end{array}$ & 400,39 & $\begin{array}{l}\text { Heat to } 2400 \text {, } \\
\text { oool to } 2350 \text {, } \\
\text { pour. }\end{array}$ & $1 \mathrm{hr} .57 \mathrm{~min}$ & 85.5 & $\begin{array}{l}\text { Poured } 0 . K_{.}, \text {molds } 1 \text { and } 2 \text { full, } \\
1 / 2 \text { rd mold. Flux ineffective. } \\
\text { Mg deposited on walls and fur- } \\
\text { nace lid. Porous } 3 \text { rd billet. } \\
\text { Xble broke on flre. }\end{array}$ \\
\hline 12 & $\begin{array}{l}2 \text { virgin biscuits } \\
\text { and } 175.3 \text { lbs. Can } \\
23 . \text { Biscuits and } \\
\text { briquettes. }\end{array}$ & 378.4 & $\begin{array}{l}\text { Heat to } 2400 \text {, } \\
\text { cool to } 2350 \text {, } \\
\text { pour. }\end{array}$ & $1 \mathrm{hr} .37 \mathrm{~min}$ & 88.5 & $\begin{array}{l}\text { Smooth pour. Mg partially ex- } \\
\text { ploded on opening furnace. De- } \\
\text { posit very heavy. Xble did not } \\
\text { break on burn out. Metal boiled } \\
\text { during melting. }\end{array}$ \\
\hline 13 & $\begin{array}{l}\text { Cans } 12 \text { and } 13 \\
46.51 \mathrm{bs} \text {. Can } 18 . \\
\text { Slugs. }\end{array}$ & 434.69 & $\begin{array}{l}\text { Heat to } 2500 \text {, } \\
\text { cool to } 2400 \\
\text { and pour. }\end{array}$ & $2 \mathrm{hr} .18 \mathrm{~min}$. & 94.8 & $\begin{array}{l}\text { Fairly smooth pour. } 3 \text { billets. } \\
\text { Xble had arch over void where } \\
\text { metal ran out. Xble did not } \\
\text { break. Arch was } 1 / 8^{\prime \prime} \text { thick. }\end{array}$ \\
\hline
\end{tabular}
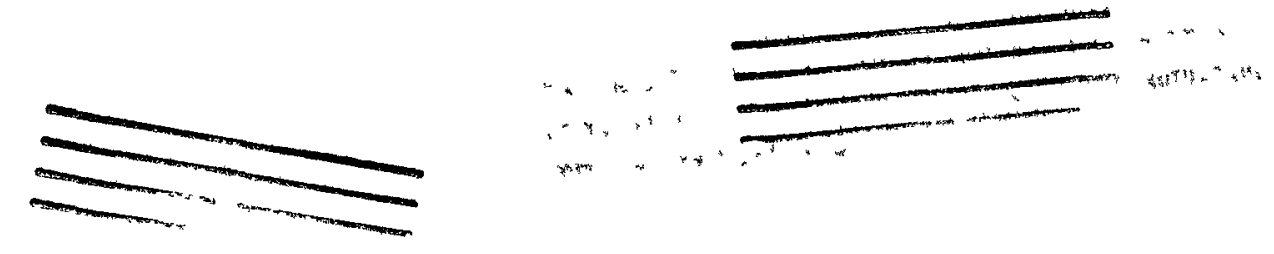